\title{
The New Romantics
}

By

\section{Ulf Lie}

University of Bergen

It is an impossible task today to keep up with the flow of American poetry appearing in weekly magazines, periodicals and small presses. It is even hard to keep abreast of the collections edited by the larger publishing houses. For whatever reason, particular poets manage to catch the academic spotlight, so a recognized short-list of contemporary poets can be said to exist. But if one can judge by the way contemporary critical judgments have fared in the past, it would be surprising, indeed, if that list should stand the pressure of the critical consensus of the next thirty years. I believe, however, that it is possible to locate broad movements in the literature of the last thirty years with dependable results, although the relative significance of these movements may change drastically.

Black Mountain poetics and especially Charles Olson's seminal essays have had an influence on contemporary poets that few will question. A survey of poets' references to these writings, whether positive or negative, bears this out. A presentation of this poetics as a post-modernist epistemology and of its place in literary history will be the task of the present paper. A few observations on its impact on contemporary poetic practice will be made in passing.

The ideas in Olson's essays did not arise in a vacuum. The ideational links to abstract expressionist painting and certain movements in music and dance are striking. Besides, performers in various arts not only knew of each other, but actually worked together; Joseph Albers, Merce Cunningham, Charles Olson, Robert Creeley and Robert Duncan all worked at Black Mountain College at some stage; others were students there; while lots of artists participated in the summer sessions at the college. Paul Goodman and John Cage are cases in point. Frank O'Hara, the New York based poet, was very close to both Olson's poetics and Jackson Pollock's paintings. I want to point out some of the 
parallels to theories of painting and music in order to show the range of application of these theories and to be able to generalize more confidently on the significance of this movement.

Contemporary poets of the United States have been called postmodernists. It is perhaps natural, since the word "modern" had been appropriated by the writers between the two world wars. "Modern" or "modernist" has come to designate not only a generation of writers, but a certain sensibility, a cluster of poetic and epistemological strategies not limited to that particular period in time. In the same manner, "post-modernism" is not merely a word used about a generation of poets after World War Two, but serves to isolate a certain school of poetry that defines itself as a reaction against the modernists as they have come to be associated with Symbolisme and New Criticism: a reaction in terms of poetics, if not in poetic practice. ${ }^{1}$

Abrams in his book on Romanticism uses "the mirror" and "the lamp" as metaphors for forms of poetic imagination. ${ }^{2}$ This distinction is not clearcut in Romantic poetry, but it is a useful one to start out with. Abrams connects Wordsworth with the mirror metaphor where the emphasis is on order discovered, on immanence; with Coleridge it is on order imposed by a synthesizing imagination, on transcendence.

Poet-modern or contemporary poetry, in adopting the Wordsworthian immanence, refutes the Coleridgean position that we find in for instance Ernst Cassirer's works which emphasize the creative faculties by which man imposes his cerebral forms on reality and responds to his own creations. Contemporary poets identify this position with the New Critical tradition, with Modernism, represented by Ransom and Tate who saw the principle of ordering in art as radically different from the ordering in nature, and with T. S. Eliot's idea of the creative imagination as formgiver and ethical imperative. Ultimately, it was the French Symbolistes who made us see the Coleridgean type of Romantic epistemology in its sharpest form: a poem as a highly self-conscious artifact where the artificial internal patterns - or a second non-natural syntax in speech and rhythm-are conducive to shifting the emphasis from the normal referential use of the words to their spiritual qualities as expressing a truer order than the natural one, because this second syntax participates in whatever it is that underlies true creativity. ${ }^{3}$ Frye seems to have expressed the ultimate logic of symbolism in his chapter on the anagogic phase in Anatomy 
$\oint$ Criticism where nature is conceived of as an expression of, or an extention of, the human mind and human desire. ${ }^{4}$

The post-moderns no longer accept the primacy of human creativity. Maybe the human forms of order created in Germany and Italy before 1945 had been too frightening. ${ }^{5}$ In the forefront of the reaction against Eliot's anthropomorphism is contemporary ecological thinking, well expressed by Jill Johnston in an essay on the composer John Cage:

Cage's heresy, of course, is his partial, sometimes total, abdication of will. The pride of the West is bound up in the "profundities" resulting from the application of mind over the brute forces of nature. Now that this pride has been shattered by so many instances of irrationality in human nature and by discoveries pointing to the finitude o human knowledge, the most advanced thought and art of our time brings man back to his proper situation within nature. ${ }^{6}$

This way of thinking has its parallel in Olson's poetics, and the attitude is perhaps best expressed by Robert Duncan, the link between the Xan Francisco Beats and the more academic Black Mountain group of poets. In "Towards an Open Universe" Duncan says:

Central to and defining the poetics I am trying to suggest here is the conviction that the order man may contrive or impose upon the things about him or upon his own language is trivial beside the divine order or natural order he may discover in them.'

There are various ideas in this passage that link it with immanence poetics: (1) the emphasis on receptivity, openness to natural forms, (2) that man exists in two worlds and has the choice between two epistemological strategies that I have identified with immanence and transcendence, and (3) a belief in organic form.

Waggoner, talking about A. R. Ammons, finds the same idea: "If there is no order discoverable in nature, the order of art is a contrivance without poetic value." 8 Stafford puts it like this in his poem "Vocation": "Your job is to find what the world is trying to be." 9

Nature is of the same order as man. Man is also an object and as such given his orders by nature, in which he is only another participant. ${ }^{10} \mathrm{He}$ is defined by the objects of his perception. The philosophical tenet of Whitehead is adopted by Olson: "By an object is meant something which will not allow us to experience at haphazard." 11 Referring to the poet, Olson explains: 
If he sprawl, he shall find little to sing but himself, and shall sing, nature has such paradoxical ways, by way of artificial forms outside himself. But if he stays inside himself, if 'he is contained within his nature as he is participant in the larger force, he will be able to listen, and his hearing through himself will give him secrets objects share. ${ }^{12}$

Jackson Pollock puts it rather more bluntly in a conversation with Hans Hofmann: "I am nature."13 The subject-object dichotomy is bridged in this Emersonian self-reliant epistemology which also resolves, in an off-hand manner, man's alienation from the world of nature. It is perhaps closer to Dadaism than Wordsworth's "wise passiveness" as it is closer to Emerson's definition of the imagination as "a very high sort of seeing, which does not come by study, but by the intellect being where and what it sees," 14 than to Denise Levertov's definition of the process:

So as the poet stands open-mouthed in the temple of life, contemplating his experience, there come to him the first words of the poem: the words which are to be his way in to the poem, if there is to be a poem. The pressure of demand and the meditation on its elements culminate in a moment of vision, of crystallization; in which some inkling of the correspondence between those elements occurs, and it occurs as words. If he forces a beginning before this point, it won't work. ${ }^{\mathbf{1 5}}$

Like Romantic poetic theory, Black Mountain poetics is primarily concerned with the genesis of poetry. Projective verse is described as "energy transferred from where the poet got it . .., by way of the poem ... to the reader." 16 Taken at face value, this is a rephrasing of the Imagist tenet of direct presentation or of Eliot's objective correlative, formulated by Hemingway as "the actual things ... which produced the emotion that you experienced .... the real thing, the sequence of motion and fact which made the emotion and which would be as valid in a year or in ten years or, with luck and if you stated it purely enough, always. . . ."17

This program of transferring to the reader the reality which inspired the poem, has its parallel in the natural sciences, i.e. Harold Morowitz's idea in Energy Flow in Biology that " The flow of energy through a system acts to organize that system." 18 The principle, as it applies to poetry, Olson calls "composition by field," the process an "event." Harold Rosenberg referred to the same process in 1952 when characterizing the American action painters:

At a certain moment the canvas began to appear to one American painterafter another as an arena in which to act-rather than as a space in which to reproduce, re-design, analyze, or "express" an object, actual or imagined. What was to go on the canvas was not a picture but an event. ${ }^{19}$ 
In order for this influx of energy to reveal itself in the poem or "field," it is necessary to block out logic and the categorizing intellect: one perception must immediately lead to another. Experience is lost when intellectualized even in an ordering of memory:

The wetness of that street, the light, the way the clouds were heavy is not description. But in memory I fear the distortion. I do not feel what it was I was feeling.

(Robert Creeley, "A Place") 20

So it becomes necessary for the artist through certain techniques to "release him from his own psychology, taste, and permit the natural flow of impermanencies as they impress themselves on the mind empty of memories, ideas, and preconceptions; in short, empty." 21 This theory of immediacy, of emptying the mind in an attitude of rapt attention, has been strong with the abstract expressionists. Franz Kline says in an interview:

we don't begin with a definite sense of procedure. It's free association from the start to the finished state. ... Painters like Rothko, Pollock, Still, perhaps in reaction to the tendency to analyze which has dominated painting from Saurat to Albers, associate, with very little analysis. A new form of expressionism inevitably followed. ${ }^{22}$

Jackson Pollock held that the modern artist is "expressing the energy, the motion and other inner forces ... expressing his feeling rather than illustrating. ..." "Painting, I think, today," he continues, "-the more immediate, the more direct, the greater the possibilities of making ... a statement." 23 Adolph Gottlieb looks back on his early period of representational painting, saying: "I was trying to force the mental image to conform to external shapes seen objectively. This retarded me."24 In his essay, "Defense of Satie," John Cage thinks that "What is unnatural about a great deal of contemporary music, neoclassicism in particular, is that it is not itself; it is not direct and instantaneously felt in form, but is derivative from whatever models of the past its particular composer chooses." 25 According to the gospel of subjective immediacy, for painters to work from sketches and for poets to revise, would be equally suspicious.

The reason for this poetic strategy is that if man blocks out his 
cultural self, he will select the true elements automatically. Like Emerson, and later the Dadaists and the expressionists, the postmodern poet of the persuasion I am talking of here, believes that in the moment of intense perception he is in harmony with cosmos, with natural creativity. As with the Romantics, this epistemology is based on a belief in Kantian a priori truths. In certain instances it will invite an abdictaion of the will to perform conscious ordering. Because a corrolary to this poetics is of course a belief in organic form. "Form is never more than an extension of content," says Creeley. ${ }^{26}$ Pound's absolute rhythm is turned into

the HEAD, by way of the EAR, to the SYLLABLE the HEART, by way of the BREATH, to the LINE

('Olson, "Projective Verse") ${ }^{27}$

This whole theory has a long tradition in American literature, from Emerson's transcendentalism through Stevens's transcendent naturalism to Olson's biological mysticism. The reliance on physical nature to give not only the Joycean epiphany, but also the form, is endemic to this poetics. James Wright assures us that "the branch will not break," 28 and Merwin in "Gift" asserts: "I have to trust what was given to me/if I am to trust anything." ${ }_{29}^{29}$ Duncan's divine or natural order, reminiscent of Emerson's Over-Soul or Jung's collective unconscious, is also man's order: "the totality of the body is involved in the act of a poem, so that the organization of words, an invisible body, bears the imprint of the physical man." 30 This direct link between poetics and epistemology is nowhere more apparent than in Gary Snyder:

Lay down these words

Before your mind like rocks. placed solid, by hands

In choice of place, set

Before the body of the mind in space and time:

$(" R i p r a p ") 31$

These poets see themselves as representative men penetrating the veil of cultural layers, uncovering the archetypal, the universal values. Wordsworth's "principal object" is the same as theirs: "to make the incidents of common life interesting by tracing in them, truly though not ostentatiously, the primary laws of our 
nature. ..."32 Robert Bly, in his epigraph to Silence in the Snowy Fields, wrote: "We are asleep in the outward man." 33 To Bly it is the human intellect that forms the barrier between inner and outer realities. His poetry is an attempt to find the underlying harmonies, like Stafford's "ideal light" and Duncan's "lady," where human consciousness perceives only discursiveness. ${ }^{34}$ This is the world that "man and objects share," in Olson's words. "Paradoxically," says Bly, "what is needed to write true poems about the outward world is inwardness." 35 This is as close to Emerson's stance as one can get. It is the immanence epistemology that Stafford expresses beautifully in the last stanza of his poem "Bi-focal":

So, the world happens twice -

once what we see it as;

second it legends itself

deep, the way it is. ${ }^{36}$

As Cage finds his fundamental characteristic of music in time length, as a contrast to silence, the Black Mountain poetics advocates a Romantic/Imagist shedding of cultural debris in search for the essential man, behind society and history. In a tone reminiscent of the Jungian distinctions of ego and self, animus and anima, logos and eros, Olson advices the poet to avoid "the lyrical interference of the ego, and let the eros, speak." 37 Emerson called them the "me" and the "not-me." Objectism, says Olson, is the getting rid of the ego, "that peculiar presumption by which Western man has interposed himself between what he is as a creature of nature (with certain instructions to carry out) and those other creations of nature which we may call objects." 38

A lot of the ideas in the poetics outlined above are expressed in Carolyn Kizer's "Singing Aloud" and A. R. Ammons's "Poetics."

\section{SINGING ALOUD}

We all have our faults. Mine is trying to write poems.

New scenery, someone I like, anything sets me off!

I hear my own voice going on, like a god or an oracle, That cello-tone, intuition. That bell-note of wisdom!

And I can't get rid of the tempting tic of pentameter, Of the urge to impose a form on what I don't understand, Or that which I have to transform because it's too grim as it is. But age is improving me: Now when I finish a poem

I no longer rush out to impose it on friendly colleagues. 
I climb through the park to the reservoir, peer down at my own reflection,

Shake a blossoming branch so I am covered with petals, Each a metaphor ...

By the time we reach middle life, we've all been deserted and robbed,

But flowers and grass and animals keep me warm.

And I remind myself to become philosophic:

We are meant to be stripped down, to prepare us for something better.

And often, I sing aloud. As I grow older

I give way to innocent folly more and more often.

The squirrels and rabbits chime in with inaudible voices.

I feel sure that the birds make an effort to be antiphonal.

When I go to the zoo, the primates and I, in communion, Hoot at each other, or signal with earthy gestures.

We must move further out of town, we musical birds and animals,

Or they'll lock us up like apes, and control us forever. ${ }^{39}$

\section{Poetics}

I look for the way

things will turn

out spiralling from a center,

the shape

things will take to come forth in

so that the birch tree white

touched black at branches

will stand out

wind-glittering

totally its apparent self:

I look for the forms

things will want to come as

from what black well of possibility,

how a thing will

unfold :

not the shape on paper - though

that, too-but the

uninterfering means on paper:

not so much looking for the shape 
as being available

to any shape that may be

summoning itself

through me

from the self not mine but ours. ${ }^{40}$

In Ammons this process of mediating through poetry sounds very much like Wordsworth's "wise passiveness." The imagination seems to be important in Olson's "What does not change/is the will to change."41 As is apparent in for example Adrienne Rich's collection The Will to Change, ${ }^{42}$ an enormous force of attention is required; a concentration, a will to perceive. Denise Levertov, like Wordsworth, emphasizes "aperception," the ability to recognize what we perceive. This process is often called "love," as in W. C. Williams and in Stafford's "Bi-focal." In Wordsworth's poetics ideas have an integral function; with the post-modernists, the emphasis is on intensity and attention, and perception of nature and natural processes.

In order to perceive things anew, to cleanse perception, a process of decreation is necessary: the shedding of layers of socially acquired stultifying habits. From this "minimal state," then, the true sources of value, manifest in the natural processes from which forms emanate, can be perceived. This is well put in Cage's essay "Defense of Satie" where he quotes Klee with approval:

It is a great difficulty and a great necessity to have to start with the smallest. I want to be as new-born, knowing nothing, absolutely nothing, about Europe; ignoring poets and fashions, to be almost primitive. Then I want to do something very modest; to work out by myself a tiny formal motive, one that my pencil will be able to hold without technique. One favorable moment is enough. The little thing is easily and concisely set down. ${ }^{43}$

This sounds like a literary history in the concrete: Emerson's celebration of the primitive state turning into Pound's "one Image in a lifetime." But it does exemplify the link between Romanticism, Imagism and Black Mountain in the importance they attach to the minimal state and the process of decreation. The Symbolistes conceived of decreation as a way of escaping from natural forms, but with the post-modernists it is mainly a question of perceiving the structures that spring out of an intensification of the perception of the familiar. By seizing on the most concrete, the most objective, one evades the ego; a lesson obviously learned from the Imagists. By burrowing deep into the self, to the collective unconscious $\rightarrow$ store-house of racial memory-one touches on the Thoreauvian bare "necessities of life," to quote from Rich's poem of that name. 
This idea of going back to square one and starting history over again has a long record in American social thinking. The Rousseau idea of contrât sociale, society as an agreement between free men, a contract that could just be anulled, appears not only in the Mayflower Compact, but also later in the Declaration of Independence. That it is a theme that has occupied not only the Romantics, but also the post-modernists can be verified by looking again at Williams's Paterson, i.e. the grasshopper poem in Book Two, Duncan's "Often I am Permitted to Return to a Meadow" and Stafford's "In Dear Detail." Carolyn Kizer, in her "Singing Aloud," speaks of the necessity of decreation in this sense: "We are meant to be stripped down to prepare us for something better." Galway Kinnell in "The Bear" identifies with the animal in order to experience to the hilt the suffering and dying of nature, with its promise of re-creation. ${ }^{44}$ Poets like Bly, Stafford, Simpson and Wright all present us with a place where man and nature merge. There is, however, a tendency in all of them, as in Whitman earlier, and for the same epistemological reasons, to posit such a union blandly. When the process of decreation features no struggle, their poems tend to be both flat and smug.

Decreation for most of these poets is a means to recreation. It is in the process of intense perception, in the act of composing, that they fashion an identity. One would perhaps expect that the corrolary to a minimal existence, a distrust of cultural forms, would be a "minimal speech," a distrust in the referential properties of language (the Symbolistes" motive for decreation). But just as the Symbolistes never stopped talking, the post-modernists never distrust language. They have instead adopted Emerson's philosophy of poetry that aims to purify the language of the tribe; it is part and parcel of their Adamic process of recreation, of naming objects anew; to deny Brecht's "alienating effects" and subscribe to the Wordsworthian tenet that words do not necessarily distort world. They believe with Richard Wilbur that it is in the poetic process that "word with world is one/And nothing dies." 43 Early W. S. Merwin echoes this same Romantic belief when reterring to "the great language itself, the vernacular of the imagination, that at one time was common to men. It is a tongue that is loosed in the service of immediate recognitions. ...." 43

The only one I am aware of in American poetry today who has followed the Symboliste theory to the end is Merwin. Gross characterizes Merwin's The Lice and The Moving Target as "post-apocalyptic, 
an inevitable end in slow process, an end already begun." 47 Here we become aware of the poems' existence on the background of silence. We jump when a word hits the page. Rich's option is to "name over the bare necessities," Levertov's to "relearn the alpha bet." It becomes a matter of stripping off the imposed cultural layers of consciousness and "march to a differentdrummer." With Merwin that alternative does not exist. He cannot even call it absurd, like Beckett. In the epigraph to The Lice Merwin takes up a quote from Heraclitus:

All men are deceived by the appearance of things, even Homer himself, who was the wisest man in Greece; for he was deceived by boys catching lice: they said to him, "what we have caught and what we have killed we have left behind, but what has escaped us we bring with us." 48

History, then, to Merwin, inasmuch as it defines, kills; "the rest we bring with us." History is what man has managed to anthropomorphize. When naming conspires with history to kill, poetry stops. Merwin no longer trusts what he has been given; the Symbolistes did, implicitly; the joke is probably on us. With Merwin the paradox is complete and the rest is silence:

It is with the others that are not there

The centuries are named for them the names

Do not come down to us

On the way to them the words

Die

(Merwin, "An End in Spring") ${ }^{49}$

Of course Merwin won't shut up. It is a stance of hopelessness that is spectacular primarily because it is so untypical of American poetry. However, Merwin has got a point. The emphasis on immediacy, on the rendering of experience through a blocking out of cultural consciousness and an abdication of the ego, the will, paradoxically anthropomorphizes nature. This is particularly so when private perception becomes the only truth, as with the postmodernists I am concerned with here. In abjuring subjectivity, this poetry becomes subjective: the voice of the speaker swamps the world; nobody else is there. Also the speaker tends to become onedimensional when there are no internal conflicts. But what is more important, the self-in-society and the society-in-the-self is spectacularly absent from much of this poetry, giving us rather less than the whole man. 
Truth is so much the inner truth that social and historical man is collapsed into the present, the eternal now of intense perception. In fact, Olson leaves out the last 3000 years of the history of Western man and calls it a dead end. The Greeks made a false turn and it has fallen to the post-Olsonians to go back and start it all over again. This romanticizing of historical development is an apolitical retirement of an elitist attitude, and a facile juggling with big ideas. Projective verse sometimes features a display of erudition and esoteric knowledge; at other times, in just limiting itself to private moments of perceiving natural objects, can never escape a minor key. There is often too little openness to a full experience in this "Luini in porcelain!"

That the attitude is elitist does not mean that it is aggressively so, as with the painter Adolph Gottlieb who said in an interview that "... the abstract expressionist says to the public (more honestly) [than the social realist]: 'You're stupid. We despise you. We don't want you to like us-or our art." $\$ 50$ One wonders just how much a need for an excuse for the lack of popular appeal motivated that statement. I believe Olson's poetry invites the same kind of criticism for its elitism, and that his attitude reflects his role as a specialist artist among other specialists in modern capitalist society that pidgeonholes human beings into roles that restrict their personality integration to the extent that exclusiveness or abdication of interpersonal relationships seem the only viable alternatives. ${ }^{41}$ In this perspective the following statement by Cage is, I believe, a real assessment of the artist's situation, and, although not intended as such, both an indictment against his society and a cry of agony:

Music then is a problem parallel to that of the integration of the personality: which in terms of modern psychology is the co-being of the conscious and the unconscious mind, Law and Freedom, in a random world situation. Good music can act as a guide to good living. It is interesting to note that the harmonic structure in music arises as Western materialism arises: disintegrates at the time that materialism comes to be questioned, and that the solution of rhythmic structure, traditional to the Orient, is arrived at with us just at the time that we profoundly sense our need for that other tradition of the Orient: peace of mind, self-knowledge.

Simultaneous with the poetics presented above-in fact, to some extent coming out of it-emerged the Beat poets: the only ones who broke with the restrictions of the avant-garde. Poets like Ginsberg, Kerouac and Corso in their diatribes against bourgeois America evinced an acceptance and a celebration of an alternative 
that brought the whole man back into poetry. I suspect it will still be a good while before academia is willing to recognize what poetic treasures these post-modernists finally left us.

\section{N O T E S}

$1 \mathrm{I}$ take the opportunity at this point to say very emphatically that I shall overstate my case in order to bring out a trend in contemporary poetics which is not applicable to the poetry of the same period. In fact, the trendiness of the poetry is much less apparent and has obvious links with symbolist, expressionist, Dadaist and surrealist theoretical positions. Even the poetics of Charles Olson and his compatriots owes many ideas to these earlier movements. So many, in fact, that the usefulness of the term post-modernism, and what has been made of the difference between modernism and postmodernism, is seriously in question.

2 M. H. Abrams, The Mzrror and the Lamp (N.Y., 1953).

3 This definition was suggested to me by professor Charles Altieri of State University of New York at Buffalo.

4 (Princeton, N.J., 1971).

5 This point has been made by Karl Malkoff in his Crowell's Handbook of Contemporary American Poetry (N.Y., 1973), p. 2.

6 "There Is No Silence Now," John Cage, ed. Richard Kostelanetz (London, 1971), p. 147. My italics. The book will subsequently be referred to as Kostelanetz, John Cage.

7 The Poetics of the New American Poetry, eds. Donald Allen and Warren Tallman (N.Y., 1973), p. 218. Subsequently referred to as Allen, Poetics.

8 Hyatt Waggoner, "The Poetry of A. R. Ammons: Some Notes and Reflections," Salmagundi, no. 22-23 (Spring-Summer, 1973), p. 287.

9 Traveling Through the Dark (N.Y., 1962), p. 94.

10 See Charles Olson, "Projective Verse," Allen, Poetics, p. 156.

11 The actual quote is from another Whiteheadian than Whitehead himself, viz. Professor Kemp Smith as cited by Robert von Hallberg in his "Olson, Whitehead, and the Objectivists," Boundary 2, II (1974), 85-111.

12 "Projective Verse," Allen, Poetzcs, p. 156.

13 B. H. Friedman, Jackson Pollock (London, 1972), p. 65.

14 Ralph Waldo Emerson, "The Poet," Selectzonsfrom Ralph Waldo Emerson, ed. Stephen E. Whicher (Cambridge, Mass., 1957), p. 233.

15 "Some Notes on Organic Form," Allen, Poetics, p. 313.

16 Charles Olson, "Projective Verse," Allen, Poetzcs, p. 148.

17 Death in the Afternoon (N.Y., 1960), p. 2.

18 Quoted by B. H. Friedman in Jackson Pollock, p. 115.

19 "The American Action Painters," Art News (September, 1952).

20 Words (N.Y., 1967), p. 85.

21 Jill Johnston, "There Is No Silence Now," Kostelanetz, John Cage, pp. 147148.

22 Seldon Rodman, Conversations Wzth Artists (N.Y., 1961), p. 108. Later referred to as Rodman. Conversations. 
23 Friedman, Pollock, pp. 176-177.

24 Rodman, Conversations, p. 91.

25 Kostelanetz, John Cage, p. 81.

26 Charles Olson, "Projective Verse," Allen, Poetics, p. 148.

27 Ibid., p. 151.

28 The Branch Will Not Break (Middletown, Conn., 1963).

29 Writings to an Unfinished Accompaniment (N.Y., 1973), p. 112.

30 Robert Duncan, "Towards an Open Universe," Allen, Poetics, p. 223.

31 Riprap E Cold Mountain Poems (San Francisco, 1966), p. 30.

32 William Wordsworth, "Preface to Lyrical Ballads," ed. of 1800, William Wordsworth, ed. Graham McMaster (Harmondsworth, Middlesex, 1972), p. 40.

33 (Middletown, Conn., 1962), p. 5.

34 See Stafford's "In Dear Detail, by Ideal Light," Traveling Through the Dark (N.Y., 1962), pp. 91-92, and Duncan's "Often I Am Permitted to Return to a Meadow," The Opening of the Field (San Francisco, 1960), p. 7.

35 "On Political Poetry," Nation, 204 (1867), 522.

36 The Rescued Year (N.Y., 1966), p. 63.

37 "Projective Verse," Allen, Poetics, p. 156.

38 Ibid.

39 Knock Upon Silence (Seattle, Wash., 1965), p. 4--5.

40 Briefings in Collected Poems (N.Y., 1972), p. 199.

41 "The Kingfishers," The Distances (N.Y., 1960), p. 5.

42 (N.Y., 1971).

43 Quoted by Cage in his "Defense of Satie," Kostelanetz, John Cage, p. 82.

44 Body Rags (Boston, 1968), pp. 60-63.

45 "Games Two" from Ceremony (1950).

46 "Notes for a Preface," The Distinctive Voice, ed. William J. Martz (Greenview. Ill., 1966), pp. 269-270.

47 Harvey Gross, "The Writing on the Void," The Iowa Review, I (1970), 92-106,

48 (N.Y., 1974).

49 Ibid., p. 7.

50 Rodman, Conversations, p. 89.

51 In spite of lip-service to an idea of art as non-autonomous. This idea is implicit in Pollocks's view that the frames of his paintings are incidental since he is expressing recurrent rhythms and processes; and explicit in Cage's essay "Defense of Satie" where he says that music is "something to do," and that "living and making a thing are not two separate acts."

52 "Defense of Satie," Kostelanetz, John Cage, p. 84. 